\title{
Ob 70. rojstnem dnevu doc. dr. Vlada Nartnika
}

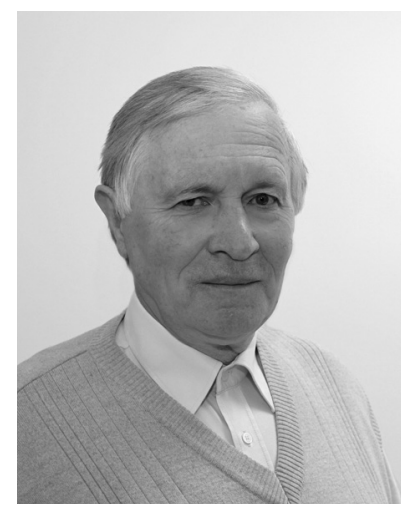

Cobiss: 1.04

Osemindvajsetega aprila 2011 je svoj 70. rojstni dan v družbi sodelavcev Inštituta za slovenski jezik Frana Ramovša ZRC SAZU praznoval doc. dr. Vlado Nartnik.

Rodil se je v Vnanjih Goricah (kot rad pove, je le nekaj ur mlajši od Osvobodilne fronte), kjer je preživel otroštvo; tudi osnovno šolo je najprej štiri leta obiskoval na bližnji Brezovici, naprej pa se je šolal na VI. (danes Plečnikovi) gimnaziji v Ljubljani. Po maturi na tedanji IV. gimnaziji se je leta 1959 vpisal na Oddelek za slovanske jezike in književnosti Filozofske fakultete Univerze v Ljubljani. Po uspešni predstavitvi diplomske naloge z naslovom Pomenska kategorija »kruh « pri profesorju Francetu Bezlaju in opravljenih izpitih iz slovenskega in ruskega jezika in književnosti leta 1965 mu je Filozofska fakulteta tedaj 24-letnemu podelila naslov profesorja slovenščine in ruščine. Za raziskavo Slovensko-ruske stilistične paralele v ljudski in umetni poeziji pa je leta 1966 prejel nagrado Prešernovega sklada za študente.

Po odsluženi vojaščini se je leta 1967 zaposlil v dokumentacijskem oddelku Zavoda za varjenje SRS v Ljubljani in se tam ukvarjal zlasti s tehnično terminologijo. Leta 1968 mu je Unescova štipendija omogočila enoletno študijsko bivanje na Jagelonski univerzi v Krakovu, Poznanju in Varšavi na Poljskem. Nato je bil tri leta univerzitetni lektor slovenskega jezika na Filozofski fakulteti v Zagrebu (19701973), dve leti v Moskvi (1973-1975), šest let v Pragi (1975-1981) in pet let v Budimpešti (1981-1986) - vmes je bil leta 1984 na Filozofski fakulteti v Ljubljani 
- izvoljen v naziv višjega predavatelja za slovenski jezik. Tudi pozneje je še večkrat [a bival v tujini, med drugim v letih 1993-1994 kot predavatelj slovenskega jezika v Katovicah na Poljskem, spomladi leta 1999 pa je v okviru programa Ceepus raziskovalno in pedagoško deloval še na Karlovi univerzi v Pragi. Dvajset let življenja (strokovnega in čisto osebnega) v tujini si mlajši kar težko predstavljamo - in vemo, da so našega sodelavca zaznamovale za vedno, tako osebno kot strokovno. Zato pa v njem vedno znova najdemo odličnega sogovorca in mentorja, tudi neverjetnega poliglota, jezikoslovca širokih obzorij in neukalupljenih pogledov na jezik.

Po vrnitvi iz Budimpešte je jeseni 1986 postal višji raziskovalni sodelavec na Inštitutu za slovenski jezik Frana Ramovša ZRC SAZU v Ljubljani in tu delal kot član komisije za pravopis, pravorečje, oblikoslovje in intonacijo glavnega uredniškega odbora pete knjige Slovarja slovenskega knjižnega jezika (SSKJ) (1991) in Slovenskega pravopisa (SP) $(2001,2003,2007)$. Za akademikom prof. dr. Francem Jakopinom, ki je leta 1989 odšel v pokoj, je prevzel vodenje inštituta in bil njegov upravnik do začetka 1992. Po nenadni smrti doc. dr. Toneta Pretnarja je bil leta 1993 povabljen za višjega predavatelja slovenskega jezika na Šlezijski univerzi v Katovicah, kjer mu je bil na podlagi končanega študija v Ljubljani in znanstvenih objav priznan naslov magistra filologije, na podlagi opravljenih predpisanih izpitov in uspešnega zagovora doktorske teze Alternativno iskanje slovniških modelov $v$ slovenskem knjižnem jeziku, ki jo je napisal pod mentorstvom prof. dr. Emila Tokarza, pa je bil spomladi 1994 promoviran za doktorja humanističnih znanosti.

Po vrnitvi na inštitut je kot naglasoslovec prevzel delo za tonematiko v slovarskem delu novega slovenskega pravopisa. Ves čas je bil tudi sodelavec dialektološke sekcije in kot narečjeslovec je leta 1994 postal član uredništva Evropskega jezikovnega atlasa (ALE). Njegov prispevek, tj. komentar in jezikovna karta ALE 462 - jumeaux (dvojčka), je v tisku v 8. zvezku ALE. Zadnja leta se skupaj s sodelavci dialektološke sekcije razdaja pri delu za Slovenski lingvistični atlas (SLA) - zanj je med drugim prispeval fonološki opis govora Plešivice in več zapisov po vprašalnici za SLA (T229 Vnanje Gorice leta 1965, T251 Janče leta 1966, T250 Studenec (Ljubljana) leta 1966 in T275 Gabrje leta 2011) ter pripravil komentarje in karte za 26 vprašanj iz pomenskih polj človek in bolezni za prvo knjigo SLA. Znanstveni svet ZRC SAZU ga je leta 2004 (in leta 2009 ponovno) izvolil v naziv znanstvenega sodelavca. Čeprav se je leta 2010 upokojil, kot zunanji sodelavec še vedno pomaga pri delu Inštituta za slovenski jezik Frana Ramovša, ne le v njegovi dialektološki sekciji, ampak kot naglasoslovec tudi pri drugih projektih inštituta.

V letih 1996-2010 je bil predavatelj na Pedagoški (pozneje Filozofski) fakulteti Univerze v Mariboru, kjer je predaval predmete Uvod v slovansko jezikoslovje, Indoevropska, praslovanska in starocerkvenoslovanska dediščina, Stara cerkvena slovanščina ter Slovenščina in južnoslovanski jeziki ter bil trikrat (leta 2000, 2005 in 2010) izvoljen v naziv docenta za slovenski jezik.

Jezikoslovno raziskovanje doc. dr. Vlada Nartnika je ob dialektologiji, naglasoslovju, slovaropisju (tu imamo v mislih predvsem njegovo sodelovanje pri SSKJ in SP) in semiotiki pogosto osredotočeno na kontrastivne prikaze nekaterih skladenjskih in oblikoslovnih kategorij v slovenščini in drugih jezikih (npr. v hrvaščini, italijanščini, španščini, madžarščini in arabščini). V svojih člankih jezikoslovno 
razmišljanje $\mathrm{v}$ izrazito osebnem slogu (tvoren je tudi pri oblikovanju jezikoslovne terminologije) pogosto ponazarja z navedki iz slovenske umetne in ljudske poezije. Ob jeziku in književnosti ga je namreč že kot lektorja na tujih univerzah zanimal tudi slovenski duhovni in zgodovinski spomin, zato ne preseneča, da je že od leta 1997 član uredništva mednarodne revije Studia mythologica Slavica. Ob tem velja izpostaviti še njegova razmišljanja o zvezdah, številih in mitologiji, skritih v slovenski slovstveni folklori, zlasti pesmih, pa tudi v naši umetni poeziji. Vedno znova preseneča s svojim briljantnim spominom (marsikomu se zdi, da zna Štrekljevo zbirko Slovenske narodne pesmi in Prešernovo poezijo ter Cankarjeva dela na pamet) ter s sposobnostjo za nenavadne asociacije in povezovanje dogodkov, ljudi, lastnih in tujih zapisov ter strokovne literature. Njegove izvirne raziskovalne metode in zanj značilen jedrnat jezikovni slog $\mathrm{z}$ mnogo informacijami so opazni $\mathrm{v}$ vseh prispevkih, napisanih za domača in mednarodna strokovna in znanstvena srečanja, in seveda tudi v strokovni monografiji Zvezdne poti: poskusi novega branja slovenskih ljudskih pesmi iz leta 1991.

Svoje raziskovalno delo je doc. dr. Vlado Nartnik vedno znal usklajevati in bogatiti z odličnim raziskovalnim mentorstvom svojim mlajšim kolegom - med drugim se je leta 2004 uspešno končalo njegovo somentorstvo pri nastajanju doktorske disertacije mlade raziskovalke Tjaše Jakop. Bolj ali manj neformalno pa jezikoslovno in človeško bogati vse svoje (tudi mlajše) sodelavce, ki jih spodbuja $k$ širokemu razgledovanju po slovenski in tuji, zlasti slovanski (strokovni) literaturi, jim svetuje in jih podpira pri inovativnem razmišljanju in samostojnem (čeprav skupinskem) raziskovalnem delu. Ob strokovni plati pa je treba poudariti zlasti slavljenčevo človeško stran - je zanimiv pripovedovalec in iskriv razpravljalec ter tankočuten poslušalec in opazovalec ljudi in dogajanja v svoji najožji okolici in širnem svetu. Želimo si, da tak tudi ostane, in mu (pri)voščimo še nekaj življenjskih sedmic.

Jožica Škofic

Foto Marko Zaplatil 